\title{
Creating cell type-specific mutants by enhancer mutagenesis
}

\begin{abstract}
Stephen Crews
Department of Biochemistry and Biophysics, School of Medicine, The University of North Carolina at Chapel Hill, Chapel Hill, North Carolina 27599, USA
\end{abstract}

Cell signaling plays an essential role in development, and knowledge of the identities of the cells sending the signal is critical. This can be a challenge, since signaling pathways and ligands are commonly used at multiple times and in multiple cell types during development. One solution to this problem is to create cell type-specific mutants using CRISPR/Cas9 to mutate enhancers that control different patterns of expression. In this issue of Genes \& Development, Rogers and colleagues (pp. 634-638) provide the first use of this method in Drosophila to solve a long-standing issue in patterning of the embryonic central nervous system.

One of the surprises to emerge from studying the molecular genetics of development is that a relatively small number of signaling pathways are used repeatedly in different cell types and at different times of development. This has been a challenge to developmental biologists, who generally need to know which cell type is doing the signaling. Ideally, mutants would exist that reduce function only in a specific cell type. These mutants most likely would reside in enhancers that control cell type-specific transcription. However, mutants of this type are rare. Fortunately, as demonstrated in the present study (Rogers et al. 2017), the advent of CRISPR/Cas9 mutagenesis and the relative ease in identifying and determining the cellular expression of enhancers now promise to make the creation of cell type-specific mutant strains routine.

The issue addressed by Rogers et al. (2017) concerns patterning of the Drosophila embryonic central nervous system (CNS). Early in development, the neuroectoderm is defined by a discrete set of CNS midline cells flanked by three bilaterally symmetrical rows of neuroectodermal cells: the ventral, intermediate, and dorsal neuroectoderm. The intermediate neuroblasts defective (ind) gene is expressed specifically in the intermediate neuroectoderm and promotes intermediate column neuroblast

[Keywords: Drosophila embryo; EGFR regulatory networks; rhomboid; intermediate neuroblasts defective; central nervous system] Corresponding author: steve_crews@unc.edu

Article is online at http://www.genesdev.org/cgi/doi/10.1101/gad.299586. 117. formation (Fig. 1A, blue). It was demonstrated that the EGFR signaling pathway is critical for the formation of intermediate column neuroblasts and the expression of ind. Furthermore, EGFR signaling is dependent on two ligands: Spitz (Spi) and Vein (Vn). Generation of functional Spi requires processing by the Rhomboid (Rho) membrane protease, and expression of rho generally indicates a cellular source of Spi signaling. However, in this case, rho is expressed in two nearby cell types: the CNS midline cells and the ventral neuroectoderm (Fig. 1A; red). The CNS midline cells are known to be a prominent source of developmental signals in Drosophila (as well as in crustaceans, fish, and mammals) and are an attractive candidate as the source of Spi and Vn signaling. However, the closer spatial proximity of the ventral neuroectodermal expression of spi and $v n$ to the ind expression domain makes this set of cells a reasonable alternative.

To directly address this issue, the investigators took advantage of detailed rho gene expression studies that had previously identified distinct enhancers: one for neuroectodermal expression and two for midline expression (Fig. 1B). Using CRISPR/Cas9 mutagenesis to create homozygous enhancer deletion mutants, they created an endogenous rho gene that lacked neuroectodermal expression yet retained midline expression (Fig. 1C, rho NEE knockout). Since the Vn ligand is likely to act redundantly with Spi, a rho NEE knockout, vn double mutant was assayed for embryonic ind expression. Only sporadic ind expression was observed, demonstrating that midline rho expression was not sufficient for normal ind expression (Fig. 1C). In contrast, deletion of the two rho midline enhancers (rho SHA MLE knockout) resulted in the absence of rho midline expression, but ind expression was normal (Fig. 1D). However, the observed ind expression could be due to $\mathrm{Vn}$ acting as a redundant EGFR ligand. This was resolved by examining a single-minded (sim) vn double mutant, which has greatly reduced midline rho expression and lacks $v n$ expression yet produces a normal ind pattern

(C) 2017 Crews This article is distributed exclusively by Cold Spring Harbor Laboratory Press for the first six months after the full-issue publication date (see http://genesdev.cshlp.org/site/misc/terms.xhtml). After six months, it is available under a Creative Commons License (Attribution-NonCommercial 4.0 International), as described at http:// creativecommons.org/licenses/by-nc/4.0/. 

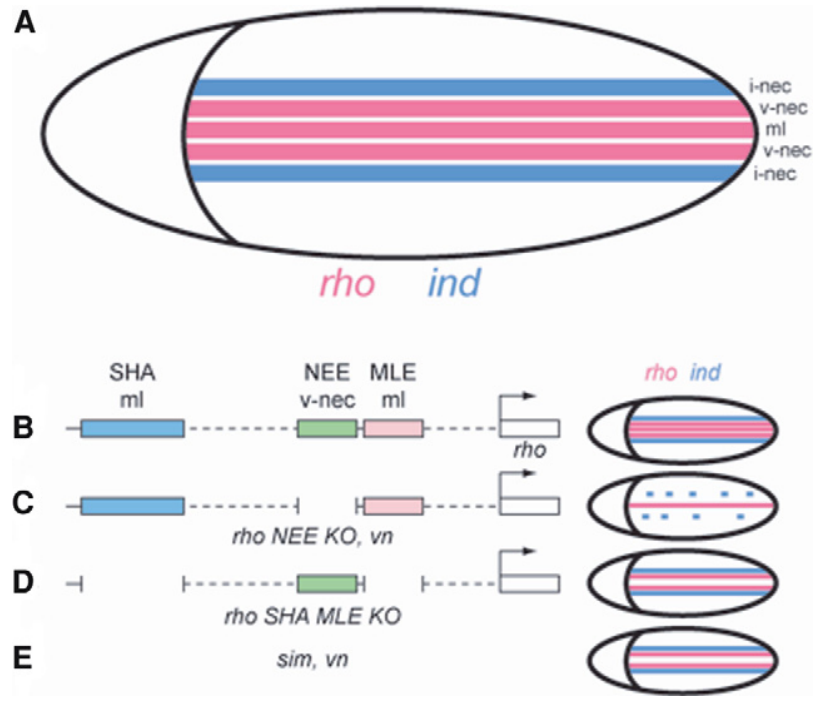

Figure 1. (A) Schematic of a Drosophila embryo showing the expression of rho (red) in the CNS midline cells $(\mathrm{ml})$ and ventral neuroectoderm (v-nec). The ind gene is expressed (blue) in the intermediate neuroectoderm (i-nec). (B) Schematic of the rho gene (not to scale) showing the two midline enhancers (SHA and MLE) and the neuroectodermal enhancer (NEE). Corresponding embryonic expression of rho and ind is at the right. $(C)$ Deletion of the neuroectodermal enhancer resulted in an incomplete pattern of ind expression. $(D, E)$ Removal of the two midline enhancers $(D)$ and analysis of a sim vn double mutant $(E)$ showed relatively normal ind expression.

(Fig. 1E). These results demonstrated that the source of Spi signaling is the neuroectoderm and not the midline.

This CRISPR/Cas9-mediated approach should prove generally useful for providing new insights into a variety of developmental and physiological questions regarding any experimental organism. One major advantage of cell type-specific mutants is avoiding pleiotropy. In many cases, this will make interpretation of phenotypes significantly clearer compared with examining typical loss-offunction mutants. It is worth noting that enhancers commonly control temporal expression, and enhancer mutants that affect only specific time windows of expression may be invaluable and help compensate for a general lack of effective temperature-sensitive mutants. Creating enhancer mutants has other benefits in understanding how genes are regulated and function. Although great progress has been made in understanding enhancer function and transcriptional regulation, the biological function of individual enhancers is not as well known. Understanding how individual enhancers function to generate patterns of gene expression is particularly important given that human disease loci commonly map to noncoding sequences and likely influence transcript levels (Maurano et al. 2012). For example, in a review on eukaryotic transcriptional autoregulation (Crews and Pearson 2009), it was noted that while the phenomenon of autoregulation was widespread, there was relatively little data regarding its biological significance-mutation of autoregulatory enhancers is a solution. Many genes have multiple enhanc- ers that can drive similar patterns of expression (shadow enhancers). That enhancer mutations can provide novel insights into biological function was demonstrated by the removal of shadow enhancers, which revealed that they confer developmental robustness to varying environmental and genetic conditions (Frankel et al. 2010; Perry et al. 2010). In an extreme case, the Drosophila sim gene has potentially eight CNS midline enhancers (Pearson et al. 2016). What is the biological contribution of each enhancer toward gene function? Analyzing enhancer mutations in vivo will provide important new insights into the control and evolution of patterns of gene expression.

Using CRISPR/Cas9 to create cell type-specific mutants by enhancer deletion requires that relevant enhancers be identified and characterized. In fact, Rogers et al. (2017) made good use of extensive enhancer analyses of the rho gene begun 25 years ago. While identifying enhancers using in vivo transgenic enhancer testing approaches is generally straightforward and successful, it can be time-consuming. Fortunately, there are genomic advances that will accelerate progress. For Drosophila, there is the existence of large-scale Gal4 transgenic projects that have assayed thousands of genomic fragments from hundreds of genes for their in vivo transcriptional activity (Manning et al. 2012; Kvon et al. 2014) as well as an annotated enhancer database (Gallo et al. 2011). These data are a useful starting point for further deletional analyses to reduce a fragment to a manageable size for enhancer mutations. Another approach should also prove particularly valuable. This involves carrying out genomewide surveys of open chromatin regions using ATAC-seq (assay for transposase-accessible chromatin [ATAC] with high-throughput sequencing) and FAIRE-seq (formaldehyde-assisted isolation of regulatory elements [FAIRE] coupled with sequencing) (McKay and Lieb 2013). These regions of open chromatin generally correspond to enhancers and promoters. With these data, one can delete these open chromatin regions individually and assay expression and phenotypes, thus bypassing the traditional transgenic method of enhancer analysis. Most useful will be identifying open chromatin regions from purified cells or nuclei corresponding to the cells of interest. This will help identify relevant cell type-specific enhancers. Recently, a comparison was made of FAIRE-seq data from purified Drosophila CNS midline cells with whole-embryo FAIRE-seq data (Pearson et al. 2016). It was demonstrated that peaks of open chromatin that are strong in the midline sample and weak in the wholeembryo sample had a high probability of being enhancers driving in vivo-relevant midline expression. With this type of information, one can go directly to using CRISPR/Cas9 for making cell type-specific enhancer mutants in vivo.

\section{Acknowledgments}

I thank Daniel McKay for helpful comments. S.C. is supported by National Institutes of Health grant NS64264. 


\section{References}

Crews ST, Pearson JC. 2009. Transcriptional autoregulation in development. Curr Biol 19: R241-R246.

Frankel N, Davis GK, Vargas D, Wang S, Payre F, Stern DL. 2010. Phenotypic robustness conferred by apparently redundant transcriptional enhancers. Nature 466: 490-493.

Gallo SM, Gerrard DT, Miner D, Simich M, Des Soye B, Bergman CM, Halfon MS. 2011. REDfly v3.0: toward a comprehensive database of transcriptional regulatory elements in Drosophila. Nucleic Acids Res 39: D118-D123.

Kvon EZ, Kazmar T, Stampfel G, Yanez-Cuna JO, Pagani M, Schernhuber K, Dickson BJ, Stark A. 2014. Genome-scale functional characterization of Drosophila developmental enhancers in vivo. Nature 512: 91-95.

Manning L, Heckscher ES, Purice MD, Roberts J, Bennett AL, Kroll JR, Pollard JL, Strader ME, Lupton JR, Dyukareva AV, et al. 2012. A resource for manipulating gene expression and analyzing cis-regulatory modules in the Drosophila CNS. Cell Rep 2: 1002-1013.

Maurano MT, Humbert R, Rynes E, Thurman RE, Haugen E, Wang H, Reynolds AP, Sandstrom R, Qu H, Brody J, et al. 2012. Systematic localization of common disease-associated variation in regulatory DNA. Science 337: 1190-1195.

McKay DJ, Lieb JD. 2013. A common set of DNA regulatory elements shapes Drosophila appendages. Dev Cell 27: 306318.

Pearson JC, McKay DJ, Lieb JD, Crews ST. 2016. Chromatin profiling of Drosophila CNS subpopulations identifies active transcriptional enhancers. Development 143: 3723-3732.

Perry MW, Boettiger AN, Bothma JP, Levine M. 2010. Shadow enhancers foster robustness of Drosophila gastrulation. Curr Biol 20: 1562-1567.

Rogers WA, Goyal Y, Yamaya K, Shvartsman SY, Levine MS. 2017. Uncoupling neurogenic gene networks in the Drosophila embryo. Genes Dev (this issue). doi: 10.1101/gad.297150.117. 


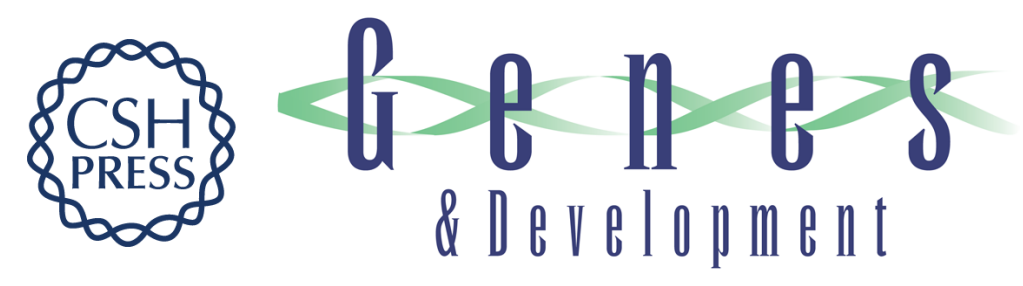

\section{Creating cell type-specific mutants by enhancer mutagenesis}

\section{Stephen Crews}

Genes Dev. 2017, 31:

Access the most recent version at doi:10.1101/gad.299586.117

\section{Related Content Uncoupling neurogenic gene networks in the Drosophila embryo \\ William A. Rogers, Yogesh Goyal, Kei Yamaya, et al. \\ Genes Dev. April , 2017 31: 634-638}

References This article cites 10 articles, 3 of which can be accessed free at: http://genesdev.cshlp.org/content/31/7/629.full.html\#ref-list-1

Articles cited in:

http://genesdev.cshlp.org/content/31/7/629.full.html\#related-urls

Creative This article is distributed exclusively by Cold Spring Harbor Laboratory Press for the first Commons License six months after the full-issue publication date (see

http://genesdev.cshlp.org/site/misc/terms.xhtml). After six months, it is available under a Creative Commons License (Attribution-NonCommercial 4.0 International), as described at http://creativecommons.org/licenses/by-nc/4.0/.

Email Alerting Receive free email alerts when new articles cite this article - sign up in the box at the top right corner of the article or click here.

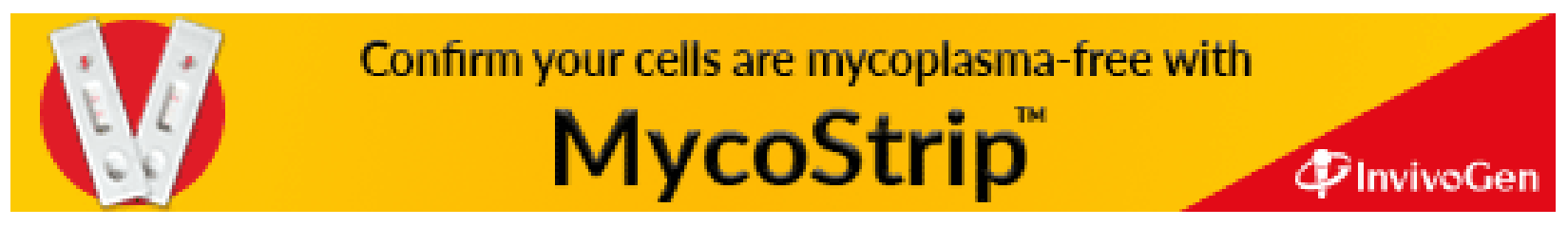

